\title{
Research on Professional Russian Teaching under the Background of Sino-Russia Cooperative Education
}

\author{
Xu Ying \\ Heihe College, Heihe Heilongjiang 164300
}

Keywords: Sino-Russia cooperative education; Professional teaching; Teaching mode

Abstract: The "one belt and one way" initiative is a new measure for China's opening up to the outside world. The implementation of this measure will inevitably affect the pattern of China's foreign trade and the personnel training mechanism of related disciplines. Under the background of "one belt and one road" initiative, China's business Russian major should base itself on fostering talents of internationalization and globalization, and explore the training mode of Russian Teaching under the background of Sino Russian cooperation in running schools. This paper analyses the current situation and existing problems of Russian Teaching in China under the background of "one belt and one road" initiative, and puts forward corresponding improvement methods.

\section{Introduction}

China's "Belt and Road Initiative" has carried out all-round cooperation with the countries, regions and international organizations that have cooperated with China and Russia. The cooperation has facilitated the increasing trade between China and Russia in countries and regions where schools operate, which requires a great deal of expertise.

\section{The situation of Russian majors in colleges under the background of Sino-Russian cooperation in running schools}

Russian major is not only a main talent platform for cross-cultural exchanges between countries in China-Russia cooperation, but also a link to promote cultural integration and cultural tolerance among countries along the route. After proposing the proposal of Sino-Russian cooperation in running schools, Russian majors and academic circles realized that college Russian teaching should be reformed according to the requirements of Sino-Russian cooperation in running schools. However, colleges and universities must realize that most Russian majors can neither balance knowledge learning nor Russian learning. There is still a long way to go for foreign language talents in Sino-Russian cooperative education. Therefore, the Russian major should continue to deepen the teaching reform and better meet the demand for Russian talents in Sino-Russian cooperative education. 


\section{The deficiencies of Russian teaching in colleges and universities}

\subsection{Teachers' ability needs to be strengthened}

Currently, most Russian majors graduate from foreign language colleges or teachers in Russian. Although they have solid knowledge of Russian, they lack the knowledge and work experience of the company. It is impossible for teachers to provide practical experience for students in Russian teaching, which is lack of pertinence and limited teaching effect. In addition, the number of Russian double-teachers in colleges and universities is also limited, which also restricts the improvement of teachers' quality. Even if some college Russian majors adopt a dual teacher system, these teachers still cannot make full use of their teaching time due to heavy workload or time conflicts. The teaching time is limited and the teaching effect needs to be improved. In addition, Sino-Russian cooperation in running schools lacks common Russian textbooks and teaching resources. The teaching of Russian teachers can only rely on their own exploration and accumulation. Although many Russian teachers have explored and innovated in accordance with the requirements of SinoRussian cooperation in running schools, the teaching resources among teachers lack interconnection and sharing.

\subsection{There is no improvement in Sino-Russian cooperation in running schools}

At present, many colleges and universities have set up Russian majors, but the current Russian teaching still cannot meet the requirements of Sino-Russian cooperation in running compound talent schools. C Most of the college Russian majors tend to teach Russian, mainly to develop students' ability of listening, speaking, reading and writing. Knowledge teaching, practice training and practice teaching are inadequate. There are not many general courses and elective courses in SinoRussian cooperative education, and the teaching system is not perfect enough. It is easy to create a knowledge gap for Russian professionals. Communication and translation in the process of SinoRussian cooperation in running schools make it impossible for them to deal with them properly. In addition, because of the different geographical location and economic development level, the countries and regions running schools in cooperation between China and Russia have different cultural backgrounds, historical traditions, customs and habits. Therefore, they have different understandings of etiquette, finance and law, and it requires that Russian teaching should be adjusted accordingly.

\subsection{The quality of practical teaching needs to be improved}

As a practical major, Russian teaching requires Russian majors to have strong practical ability and application ability. At present, Russian majors in Colleges and universities mainly focus on theoretical teaching and Russian teaching, insufficient attention is paid to teaching and practical teaching, the breadth and depth of school-enterprise integration of practical teaching needs to be strengthened. Although the practice teaching of Russian has carried out in Colleges and universities, the choice of practice teaching bases has not been fully integrated with the Sino-Russian cooperatively-run enterprises, students cannot contact the culture, knowledge and skills of the countries and regions along the Sino-Russian cooperatively-run schools in practice teaching, and there are shortcomings in practical ability. Colleges and universities lack in-depth interaction and targeted improvement in the formulation of talent training programs. In addition, the development of modern educational technology has not been fully utilized to carry out simulation practice teaching and virtual scene simulation transaction. Sino-Russian cooperation in running schools has expanded the market to more than one hundred countries, regions or international organizations. 
Russian knowledge and etiquette are more diversified and diversified. However, the practical teaching of enterprises is limited to the national and regional markets and cannot cover all of them, which needs to be supplemented by simulation and virtual teaching.

4. Countermeasures to improve the teaching of Russian majors in universities under the background of Sino-Russian cooperative education

\subsection{Strengthening the construction of Russian professional teaching}

Strengthening the teaching ability of Russian majors in colleges and universities, and building Sino-Russian cooperation in running schools involves many countries, regions and international organizations, with diverse cultures, rich knowledge of financial and legal laws, and different regulations. This is also a new challenge for teachers in Russian universities, which need to keep learning and enrich their knowledge. First of all, college Russian teachers should improve their teaching ability through self-study, participation in training, and strengthening communication. Self-study refers to the enrichment of Russian professional knowledge and preparation of study results by studying the cultural, financial and economic regulations, cross-cultural exchanges and domestic related research of national, regional and international organizations that run Sino-Russian cooperation. Participation in training means that Russian teachers in colleges and universities actively participate in teaching forums, roundtables and training, especially foreign language teaching. Exchange learning refers to the active exchange and cooperation between Russian teachers and non-Russian students such as English and Arabic, sharing copywriting resources, exchanging teaching experience and teaching methods, and giving full play to the exchanges and cooperation between teachers. Second, college Russian teachers should personally go to the practical teaching bases such as Sino-Russian cooperation in running schools, familiar with foreign exchange and translation practices, translate product introductions, operation instructions, maintenance guides, foreign trade correspondence and contracts. Improve their knowledge and abilities. Eligible colleges and universities should also carry out educational exchanges and teacher exchanges with universities in countries and regions along the Sino-Russian cooperation, and send teachers to foreign universities to inspect and make teachers familiar with the culture and knowledge of these countries, and arrive in various areas as soon as possible. Third, Sino-Russian cooperation in running schools involves a wealth of Russian knowledge, requiring teachers to have a strong ability to summarize and organize, and make full use of limited classroom teaching time for key explanations. At the same time, teachers should combine classroom teaching with extracurricular teaching, especially to make full use of online teaching and new media teaching to expand classroom teaching.

\subsection{Enriching the teaching contents of Russian majors in colleges and universities}

In the context of Sino-Russian cooperation in running schools, Russian professional students are required to have solid Russian knowledge, including the financial and legal aspects of the countries, regions and international organizations that Sino-Russian cooperation in running schools. They should fully understand the economic policies, social security and employment policies, ecoenvironmental protection policies of these countries, and be proficient in Russian communication. Therefore, for Russian teaching, it needs to actively enrich the knowledge of Sino-Russian cooperation in running schools. First, actively improve the Sino-Russian cooperation in running schools and form a three-dimensional Russian teaching content system in Central Asia, Southeast Asia, South Asia and the Middle East. The second is to combine general education with marketoriented professional courses. 
Opening a general course to introduce and explain the cross-cultural exchanges between the Chinese and Russian mainstream countries in legal Russian language education, so that students form an overall understanding. Professional courses in international marketing, Russian negotiations, international trade theory and policy.

\subsection{Promoting practical teaching of Russian majors in colleges and universities}

The quality of learning has further promoted the integration of school-enterprise teaching. Under the initiative of Sino-Russian cooperation in running schools, the Russian profession has made great achievements, but the Russian profession needs to adapt to the requirements of Sino-Russian cooperation in running schools.

First of all, based on the requirements of Sino-Russian cooperation in running schools, the integration of the practical teaching of school-enterprise in Russian colleges should be adjusted accordingly. Enterprises that run schools and enterprises in cooperation should choose enterprises that have business in China, Russia, or international organizations, such as cross-border ecommerce, foreign trade enterprises, and foreign tourism. Universities and enterprises jointly develop training programs to dynamically adjust the skills and skills of Russian professionals according to market needs and business needs, and strengthen and improve teaching accordingly. Conditional universities and businesses can conduct order training. Colleges and universities should improve the proportion of practical teaching in enterprises. The mentor of enterprise practice base should strictly control the quality of practical teaching, and strengthen guidance, and timely feedback to universities on the problems existing in practical teaching. Enable universities to make improvements and adjustments based on feedback.

Secondly, it is necessary to establish a "double-skilled" faculty team, attract foreign-funded enterprises with experienced talents, and enrich the faculty. In practical and practical professional courses, more front-line employees are hired to teach, more to communicate and coordinate with dual-teachers, and to teach in their spare time.

Finally, it is necessary to make full use of modern information technology to establish simulation teaching. Using the computer network, the transaction simulation environment involving China and Russia in the country and region was constructed, and the actual situation of Sino-Russian cooperation in running schools was simulated to provide students with immersive language, culture and international learning platform to cultivate students' learning ability and practical ability.

\section{Conclusion}

Sino-Russian cooperative education is a new impetus for China's economic development and world economic development. The Russian majors in colleges and universities should grasp the current good situation, constantly adjust their own skills according to the needs of Sino-Russian cooperation in running schools, and adopt corresponding reform measures in the teaching to train the corresponding "Plus-Russia" compound talents for Sino-Russian cooperation in running schools.

\section{Acknowledgments}

Foundation projects:

1) One of the achievements of Heilongjiang Art Science Planning Project "Innovative Model of Russian Teaching for Art Majors under the Background of Sino-Russian Cooperation in Running Schools" (Project No. 2017D076)

2) One of the achievements of Heihe University's Higher Education Reform Project "Research and Practice of Innovative Russian Teaching Model for Fine Arts Majors under the Background of 
Sino-Russian Cooperation in Running Schools" (Project No. xjg1736)

\section{References}

[1] Liu Xin, Zhao Haonan. Research on Russian Practice Base Construction and Teacher Training in Applied Undergraduate Universities [J].Learning Theory, 2013 (3).

[2] Lv Shisheng. The theoretical basis for the orientation of Russian discipline [J]. Foreign language circles, 2013 (4).

[3] Yan Ming. [J].Journal of Foreign Languages, 2015 (5).

[4] Yang Wenhui. On the Strategic Idea and Model Construction of College Russian Teaching Course [J].Journal of Guangdong University of Foreign Studies, 